\author{
Гурдуз Андрій, \\ кандидат філологічних наук, доцент \\ кафедри української мови і літератури \\ Миколаївський національий \\ університет імені В. О. Сухомлинського
}

\title{
ХУДОЖНЯ ПОЛІВАЛЕНТНІСТЬ ЛЕГЕНДАРНО-МІФОЛОГІЧНОГО ОБРАЗУ: ФАКТОРИ АНАЛІЗУ
}

У пропонованій статті уточнено параметри художньої полівалентності легендарноміфологічного образу, яка є ключовою в механізмі ізоморфізму традииійних структур $i$ важливою в їх системному (вертикальному) аналізі. Запропоновано відповідну термінологію, уперше здійснено функиіональну характеристику опосередкованої художньої валентності традииійної структури. Узагальнено схему виявлення амплітуди інтерпретації легендарноміфологічної структури на прикладі популярних у літературі початку XXI cm. метатекстів трактувань образів єдинорога і Мінотавра.

Ключові слова: художня полівалентність, метатекст, амплітуда інтерпретації, легендарно-міфологічна структура, аналіз, образ, інсталяція.

Gurduz A. The artistic polyvalence of the legendarily-mythological image: the factors of the analysis.

In this article the parameters of the artistic polyvalence of the legendarily-mythological image are specified. That polyvalence is the key factor in the mechanism of isomorphism of traditional structures and it is an important one in their (vertical) analysis of the systems. The proper terminology is offered, the functional description of the mediated artistic valency of traditional structure is realized for the first time. The chart of exposure of the amplitude of the legendarily-mythological structures interpretation is generalized on the example of popular in literature of the beginning of the XXI century interpretations metatexts of the images of the Unicorn and Minotaur.

Keywords: artistic polyvalence, metatext, amplitude of interpretation, legendarilymythological structure, analyses, image, installation.

Вивчення функціонування легендарно-міфологічних структур класичних чи новішої природи - залишається пріоритетним у літературній компаративістиці, попри помітне в останні десятиліття посилене студіювання цієї площини. Застосування психоаналітичного, міфопоетичного, герменевтичного й інших методів дослідження сприяє посиленню продуктивності таких праць (зокрема, присвячених корпусам античної чи 
біблійної міфології, неоміфології - фаустіани, гамлетіани, донжуаніани, донкихотіани, франкенштейніани й ін.), однак - швидше розвідок горизонтального (лінійного) типу, тимчасом як для інтенсифікації вивчення їх вертикального шару необхідний перегляд концепцій дослідження традиційних образів i сюжетів. Спектр останніх варто розглядати не як суму видозмінюваних у культурному процесі художніх одиниць усередині певного тематичного блоку (наприклад, образу єдинорога), а як системний політематичний й ізоморфний метатекст, трансформаційна динаміка складників якого внутрішньо взаємозумовлена. Ідея розроблення такого ракурсу проблеми намічена в східноєвропейському літературознавстві - у працях В. Багно (на рівні застереження від хибних узагальнень [1, с. 239]) i А. Нямцу [зокрема, див.: 2, с. 337-350], а відповідна концепція вперше теоретично мотивована і практично розвинена автором цієї статті ([3], [4], [5], [6] та ін.). Окремі роботи західних дослідників містять елементи подібного студіювання, хоча часом позбавлені належного методологічного обгрунтування й потребують більшої системності [наприклад, див.: 7; 8]. Метою пропонованої розвідки бачимо уточнення параметрів художньої полівалентності легендарноміфологічного образу (порівняймо 3 загальними позиціями про них [2, с. 337-350]), яка є ключовою в механізмі ізоморфізму традиційних структур i важливою в їх системному (вертикальному) аналізі. Нами запропоновано відповідну термінологію, а також уперше подано функціональну характеристику опосередкованої художньої валентності традиційної структури. Принциповим при цьому $\epsilon$ узагальнення схеми виявлення амплітуди інтерпретації легендарно-міфологічної одиниці на прикладі популярних у літературі початку XXI ст. метатекстів трактувань образів єдинорога i Мінотавра. Майже на висвітлена в літературознавстві (дотична до питання контамінації - явища наступного порядку - і при цьому достатньо автономна), заявлена проблема, в такий спосіб, актуальна; іiі розроблення перспективне для вдосконалення досліджень традиційних структур різних рівнів.

При всій можливій прогресивності здійснювані досі українськими і 
загалом слов’янськими вченими дослідження традиційних структур переважно замкнені на власному тематичному матеріалі, що, 3 урахуванням слабкого дотримання принципу послідовності всередині проблемних кластерів, певно знижує результати наукових напрацювань та специфічно їх «герметизує». Прикладами цьому $є$ кандидатські дисертації Г. Драненко «Особливості переосмислення міфу про Алкмену та Амфітріона в літературі XX ст.» 2004 р., Н. Кузнецової «Міф про Мінотавра в культурному контексті ХХ століття» 2009 р., Н. Гури «Інтерпретація міфу про Іфігенію в європейській літературі» 2012 р., Л. Майстренко «Типологія і трансляція міфологеми еросу у творах Вергілія, Овідія, Данте, Шекспіра» 2016 р. або Т. Прищепи «Динаміка міфологізації образу Франкенштейна в літературі та культурі XX-XXI століть» 2017 р. Очевидна невідповідність (лінійного) способу наукового висвітлення природі новітніх - стереоскопічних - інтерпретацій легендарно-міфологічного матеріалу $\mathrm{y}$ текстах iз його глибоким філософським переосмисленням i концептуалізацією. У цьому контексті варто назвати твори О. Грякалова «Смерть єдинорога» 2003 р., С. Павлоу «Ген» (у слов’янському просторі відомий як «Троянський кінь») 2005 р., В. Пелевіна «Шолом жаху. Міф про Тесея і Мінотавра» 2005 р. та «Empire V» 2006 р. і «Бетман Аполло» 2013 р., С. Коллінз «Голодні ігри» 2008-2010 pp., Г. Л. Олді «Бик із машини» 2017 р. i деякі інші. Осягнення пропонованих названими письменниками дифузних сполучень різнорівневих традиційних структур передбачає здійснення їх аналізу, зокрема, в нелінійний спосіб, коли особливо актуалізується аспект ізоморфізму відповідного матеріалу i, відповідно, питання його художньої валентності.

Виявлення типологій конститутивних для певних легендарноміфологічних образів і мотивів ознак дозволяє говорити про особливі смислові зв’язки між цими автономними структурами, на порядок збільшуючи в такий спосіб ресурс їх потенційних інтерпретацій. Сукупність однорідних легендарно-міфологічних одиниць при цьому постає як складна гетерогенна система, де окремі традиційні елементи виступають (часом ситуативно) 
своєрідними первнями, функціонально й логічно продовженими іншими структурами (так, Голем передує образу творіння Франкенштейна, а Фауст постаті самого Франкенштейна). Тобто між окремими тематичними лініями (големіана, фаустіана, франкенштейніана й ін.) окреслюються раніше не виявлювані чи визначувані нечітко своєрідні причинно-наслідкові зв'язки. Показову вертикаль образів указує А. Нямцу: «Лазар - Дракула Франкенитейн» [2, с. 337].

Одним із перших кроків на шляху системного аналізу легендарноміфологічних структур є характеристика амплітуди їх інтерпретації. Показове тут зіставлення суміжного і дотикового полів бінарних опозицій у тематичних амплітудах трактувань образів єдинорога i Мінотавра як символічно протилежних, що в європейській культурі набули асоціативності відповідно 3 добром і злом. Аналіз репрезентативних творів для інтерпретаційного масиву образу єдинорога виявляє такі межі переосмислення: а) чарівний кінь класичного вигляду $-(\rightarrow$ антропоморфізована постать із поєднанням рис людини і коня $\rightarrow$ ) - образ людини; б) представник виду тварин - окремої раси; тварина в) білого кольору - чорного (або іншого) кольору, г) (за розміром) велика - маленька, г) доросла - єдинороженя, д) безсмертна (яку можна / не можна вбити) - смертна; відносно людей е) добра (в подобі людини може відчувати кохання) - зла, є) жертва - агресор, ж) дика - ручна [9, с. 113], 3) за конкретністю / абстрактністю: істота (людина) - символ, знак. 3 іншого боку, дещо більш потужна за обсягом мінотавріана демонструє наступний спектр інтерпретаційних опозицій: а) за ознакою унікальності: Мінотавр - мінотаври; б) за статтю: Мінотавр - жінка-мінотавр; в) за віком: доросла істота - дитина; г) за характером: злий - добрий; г) відносно людей: ворог - друг (учитель, пророк); д) за функцією в творі: чудовисько - жертва; е) за місцем перебування: в лабіринті - в лісі (місті); є) за наявністю інтелекту / духовності: звір - розумна істота (людина), ж) за конкретністю/абстрактністю: істота (людина) - символ, знак [4, ч. 2, с. 55].

У межах амплітуди інтерпретації легендарно-міфологічної структури 
перебуває потенціал іï художньої валентності - прямої й опосередкованої. Якщо перший різновид художньої валентності так чи інакше потрапляв в об’єктив літературознавців [2, с. 337-350; 10, с. 87], то розвідки стосовно другого іï типу відсутні. Спектр опосередкованої художньої валентності (яка характеризує здатність стереотипної структури інсталюватись у систему «сторонніх» щодо неї традиційних образів, сюжетів і мотивів) визначається неординарними письменницькими художніми рішеннями $\mathrm{i}$ може розширюватись у силу часової зміни соціально-культурних реалій. Результат комбінаторики віддалених стереотипних тематичних корпусів стимулює уяву читача, сприяє піднесенню горизонту очікування й ефекту залучення реципієнта до мистецької гри, коли той встановлює логіку «пропущених» асоціативних ланок між новим поєднанням (атрибутів) двох і більше ключових легендарно-міфологічних структур. Прикладом опосередкованої художньої валентності є постать Адама-Франкенштейна у фентезійній драмі реж. С. Бітті «Я, Франкенштейн» 2014 р. (США - Австралія), ключовій для розуміння еволюції франкенштейніани початку XXI ст. i поверхово та некоректно прокоментованій у дисертації Т. Прищепи [11, с. 84]. Франкенштейнівська лінія в іiі класичному розумінні тут проходить як додаткова, але постать Адама-воїна центральна: у результаті він стає каталізатором протистояння сил добра і зла й фактично очолює битву за добро. Семантичний потенціал франкенштейніани, а також ангелології, мінотавріани, вампіріади й інших аналогічних інтерпретаційних корпусів XXI ст. може бути висвітлений уповні тільки через звертання до компаративного аналізу вертикального типу 3 залученням генетичного підходу [5].

Фентезійний акцент кардинально змінює семантичні вектори переосмислень легендарно-міфологічного образу, мотиву, сюжету і в силу жанрової природи уможливлює поєднання в синтетичній реальності ряду світів. Під час зіткнення 3 не характерною для нього художньою дійсністю матричний образ вібрує і виявляє нові якості, демонструє розширення валентності, автоматично виходячи за межі поля свого інтерпретаційного корпусу. За таких 
умов продовження вивчення цього образу в традиційній лінійній перспективі (як у роботах Н. Кузнецової [12] чи Т. Прищепи, а в другій, крім того, не враховано принципові в обговорюваній площині праці з франкенштейніани зокрема, монографії XXI ст. С. Т. Хічкок, Б. Куррана) схематизує результати дослідження, примітивізує їх і може сприяти некоректним узагальненням.

Частіше вияви опосередкованої і, як максимум, оказіональної художньої валентності легендарно-міфологічних структур зустрічаємо в творах кінця XX - початку XXI ст., яскраві приклади чому - «Шерлок Холмс проти Дракули» Д. С. Девіса 1995 р., «Ван Хельсинг» реж. С. Соммерса 2004 р., «Вампір в Атлантиді» А. Дей 2011 р., «Шерлок Холмс проти марсіан» 2014 р. i «Бик із машини» 2017 р. Г. Л. Олді, «Месники» і «Бетмен проти Супермена: На світанку справедливості» реж. 3. Снайдера 2016 р. та ін. Скажімо, контамінація античного контексту i науково-фантастичної складової дозволяє Г. Л. Олді оригінально проводити в «Бику 3 машини» ідею війни / протистояння світів, ближчу i реалізовану раніше в вампіріаді («Ді, мисливець на вампірів» Х. Кикуті 1983 р., «Імперія страху» Б. Стеблфорда 1988 р., «Пастир» реж. С. Стюарта 2011 p. (США) тощо) i семантично пряму для франкенштейніани (наприклад, «Франкенштейн: Мертвий і живий» Д. Кунца 2009 р. і под.). При цьому ключовим у романі Г. Л. Олді стають образ i комплекс Мінотавра, що підтверджує наше положення про фактичну універсальність образу людинобика й необмеженість його інсталяції в тіло культурного процесу [детальніше див.: 4, ч. 2, с. 55]. Аналіз мінотавріани свідчить про послідовне проведення віртуалізаційної лінії в іiі зразках XXI ст., i це також органічно світовим тенденціям переосмислення ряду легендарноміфологічних образів перших десятиліть XXI ст.

Розроблення питань художньої валентності легендарно-міфологічних структур різної природи особливої актуальності набуває в умовах постмодернізму 3 його аплікаційною філософією i глобальним переосмисленням культурного спадку, коли на перший план виходять традиційні структури, і власне статус таких художніх одиниць вібрує й отримує 
імпульс до розмивання. Положення нашої статті можуть бути розвинені в світлі перспективних масштабних досліджень ізоморфізму міфологічних, нео- i квазіміфологічних явищ і процесів у сучасній літературі й мистецтві загалом.

\section{Література}

1. Багно В. Е. «Коэффициент узнавания» мировых литературных образов / В. Е. Багно // Труды Отдела древнерусской литературы / Рос. акад. наук. - СПб. : Дмитрий Буланин, 1997. - Т. 50 [редкол. : А. А. Алексеев и др.].C. $234-241$.

2. Нямцу А. Миф. Легенда. Литература : (теоретические аспекты функционирования) : монографія / А. Нямцу. - Черновцы: Рута, 2007. - 520 с.

3. Гурдуз А. Постійність рухливого: ізоморфізм ключових традиційних образів і мотивів у літературі / А. Гурдуз // Зарубіжна література в школах України. - 2009. - № 12. - С. 63-64.

4. Гурдуз А. Літературна мінотавріана XX - початку XXI ст. / А. Гурдуз // Зарубіжна література в школах України. - 2009. - № 1 (ч. 1). С. $13-17$; № 6 (ч. 2). - С. 51-56.

5. Гурдуз А. Трансформації франкенштейніани початку XXI століття : фентезійний акцент / А. Гурдуз // Літератури світу : поетика, ментальність i духовність : зб. наук. пр. ; гол. ред. С. І. Ковпік. - Кривий Ріг : ДВНЗ «Криворізький національний університет», 2016. - Вип. 7. - С. 42-51.

6. Гурдуз А. Мінотавр в українській літературі XXI століття: версія Генрі Лайона Олді / А. Гурдуз // Науковий вісник Миколаївського національного університету імені В. О. Сухомлинського. Сер. : Філологічні науки : (літературознавство) : зб. наук. пр. / за ред. О. С. Філатової. - Миколаїв : МНУ ім. В. О. Сухомлинського, 2018. - Вип. 2 (22). Листопад. - С. 32-36.

7. Hitchcock S.T. Frankenstein: A Cultural History/ Susan Tyler Hitchcock.New York, N. Y. : W. W. Norton, 2007. - 392 p.

8. Ziolkowski T. Minos and the Moderns : Cretan Myth in Twentieth-Century Literature and Art / T. Ziolkowski. - Oxford : Oxford University Press Us, 2008. 
9. Гурдуз А. І. Амплітуда переосмислення образу єдинорога в літературі XX - першого десятиліття XXI ст. / А. І. Гурдуз // Новітня філологія. Миколаїв : Вид-во Чорномор. держ. ун-ту імені Петра Могили, 2010. - № 37. C. 99-115.

10. Традиційні сюжети та образи : монографія / авт. проекту й упорядн. : А. Р. Волков. - Чернівці : Місто, 2004. - 442 с.

11. Прищепа Т. В. Динаміка міфологізації образа Франкенштейна в літературі та культурі XX-XXI століть : дис. ... канд. філол. наук ; спец. : 10.01.04 - література зарубіжних країн / Т. В. Прищепа; Дніпров. нац. ун-т ім. Олеся Гончара. - Дніпро, 2017. - 213 арк.

12. Кузнецова Н. В. Миф о Минотавре в культурном контексте XX века : автореф. дисс. на соискание ученой степени кандидата культурологи : спец. 24.00.01 «Теория и история культуры» / Н. В. Кузнецова ; Моск. гос. ун-т им. М. В. Ломоносова. - М., 2009. - 25 с. 